\title{
Economic Development and Structural Transformation
}

\begin{abstract}
Technological change affects the sectoral composition of an economy. But, (why) do economic sectors matter? We revisit three schools of theory on economic development: the "classical," the neo-Schumpeterian and the neoclassical school. While the latter two camps are agnostic toward the role of economic sectors in development, the first places a special emphasis on sectoral-particularly, manufacturing-development as an engine of growth. In the tradition of W. Arthur Lewis and Nicholas Kaldor among others, development is thus envisaged as "structural transformation" of production and employment. We show that the classical view, and its more recent iterations, continues to find empirical support in its lasting explanatory power.
\end{abstract}

Keywords Development theory - Structural transformation • Economic sectors $\cdot$ Neoclassical theory $\cdot$ Schumpeter $\cdot$ Lewis model

\subsection{Three Schools of Economic Development Theory}

Palma (2005) usefully outlines three schools broad schools of theory on economic development, in terms of how each views sector and activity specificity (and includes caveats for oversimplicity). There are two schools-neoclassical and neo-Schumpeterian-which are, in general, based on the assumption that an equilibrating process due to marginal

(C) The Author(s) 2020

L. Schlogl and A. Sumner, Disrupted Development and the Future of Inequality in the Age of Automation, Rethinking International Development series, https://doi.org/10.1007/978-3-030-30131-6_2 
returns leads to an optimal allocation of factors of production at least in the medium-to-long term. These schools see little importance in sectors although the latter is concerned with activities. In contrast, a third school-a Lewisian or Kaldorian or even simply, the classical school, given its historic roots-where sectors matter as does activity specificity. This is to the point that manufacturing is special as it has increasing returns to scale (in direct contrast to neoclassical theory of constant or decreasing returns to scale), provides a host of spillovers and there is a core premise that equilibrium may not prevail and a structural imbalance-in the sectoral distribution of factors of production-which is not optimal for economic development and growth may persist even in the long run.

The first school-neoclassical theory-is indifferent to sectors and specificity of economic activity (Herrendorf, Rogerson, \& Valentinyi, 2014). This school is represented by Solow convergence models (traditional and augmented), endogenous models based on increasing returns, and models based on market imperfections in technological change. Although the importance of the shift to higher productivity is not disputed in neoclassical economics, a one-sector model of economic growth has become standard in macroeconomics. In this onesector model of economic growth there is no account of the process of inter-sectoral reallocation of economic activity or structural transformation. This is because, in the neoclassical growth model (of Solow, 1956), growth is driven by incentives to save, accumulate physical and human capital, and innovate. The neoclassical position is that poor countries will grow faster than rich countries and countries with the same technology will converge at a similar income level (see discussion in Sutirtha, Kessler, and Subramanian, 2016). A second school-neo-Schumpeterian-like the neoclassical school, is indifferent to sectors too. However, this neo-Schumpeterian school is concerned with economic activities specificity. This school is associated with Roemer and the neo-Schumpeterians who argue that research and development matter, but that there is nothing special about manufacturing in terms of increasing returns to scale of manufacturing or positive spillovers for example.

The third school, which may be labeled as the Classical School given its roots in Ricardo and classical political economy or the Lewis-Kaldor School given the elucidation of economic development as structural transformation in both Lewis (see for example, 1954, 1958, 1969, 1972, 1976, 1979) and Kaldor (1957, 1967, 1978 [1966]) among others such 
as Chenery (1960, 1975, 1979), Hirschman (1958), Myrdal (1957a, 1957b, 1968), and Thirlwall $(1982,2011)$. What binds this group together is that growth dynamics are dependent on the activities being developed and the capital accumulation effects of manufacturing. Thus, issues such as technology, externalities, balance of payment sustainability, and convergence with advanced countries are a function of the size, strength, and depth of manufacturing. ${ }^{1}$ Many such as Rodrik (2016) argue that most services are (i) non-tradable, and (ii) not technologically dynamic, and that (iii) some sectors are tradable and dynamic, but they do not have the capacity to absorb labor. Similar shortcomings can be observed about the manufacturing sector. A significant share of manufacturing is (i) non-traded (even though it is tradable), (ii) much of manufacturing in developing countries is not technologically advanced (at least in relative terms to other modern sectors), and (iii) where some manufacturing sectors are technologically dynamic, they may not create much employment, as some service sectors do.

Empirically, McMillan and Rodrik (2011, p. 1), in taking sectoral and aggregate labor productivity data empirically, show that the transfer of labor and other inputs to higher productive activity is a driver of economic development, as Lewis hypothesized. They go on to note that structural transformation (ST) can in fact be growth-enhancing or growth-reducing depending on the reallocation of labor. This is an important point and relates to the multiple modes of ST and direction between sectors, which may be regressive as well as progressive in the sense of productivity gains or losses. They show how structural change had been growth-enhancing in Asia because labor has transferred from low to higher productivity sectors. However, the converse is the case for sub-Saharan Africa and Latin America because labor has been transferred from higher to lower productivity sectors and this has reduced growth rates. ${ }^{2}$

McMillan and Rodrik (2011) find that countries with a large share of exports in natural resources tend to experience growth-reducing structural transformation and, even if they have higher productivity, cannot absorb surplus labor from agriculture. In a similar vein, Gollin, Jedwab, and Vollrath (2016), too, argued that natural resource exports drive urbanization without structural transformation because natural resources generate considerable surplus which is spent on urban goods and services, and urban employment tends to be in non-traded services. McMillan and Rodrik (2011) also find that an undervalued (competitive) exchange rate, which operates effectively as a subsidy on industry and labor market characteristics 
(so labor can move across sectors and firms easily), leads to growth-enhancing structural transformation. In a similar vein, Diao, McMillan, Rodrik, and Kennedy (2017) argue that the most recent growth accelerations in the developing world, unlike East Asia's historical experience, have not been driven by industrialization but by within-sector productivity growth (in Latin America) and growth-increasing structural transformation, but this has been accompanied by negative labor productivity growth within nonagricultural sectors (in Ethiopia, Malawi, Senegal, and Tanzania). Others, such as Herrendorf et al. (2014), concur empirically with the argument that the sectoral composition of economic activity is key to understanding not only economic development but also regional income convergence, productivity trends, business cycles, and inequality in wages. ${ }^{3}$

\subsection{Economic Development with Structural Transformation: Kaldor ReVisited}

The theoretical basis or model of economic development of the third school, as noted, is that associated with Nicholas Kaldor and Arthur Lewis. The special characteristics of manufacturing argument is predicated on the work of Kaldor (1967). Kaldor posited that economic development requires industrialization because increasing returns in the manufacturing sector mean faster growth of manufacturing output which is associated with faster economic growth. Kaldor's arguments were because backward and forward input-output linkages are strongest in manufacturing, and the scope for capital accumulation, technological progress, economies of scale, and knowledge spillover are strong. Further, there is a strong causal relationship between manufacturing output growth and labor productivity because of a deepening division of labor, specialization, and learning-by-doing, and the scope for productivity gains is large due to economies of scale.

Kaldor (1978 [1966], 1967) outlined a set of empirical regularities which came to be known as "Kaldor's growth laws" that are framed around ST (see for discussion in particular Storm, 2015; Targetti, 2005). ${ }^{4}$ Kaldor (1967) sought to explain the economic development of Western Europe through the development of manufacturing which he argued was the engine of growth for every country at every stage of economic development. He posited that: (i) Economic development requires industrialization because increasing returns in the manufacturing sector mean faster growth of manufacturing output which is associated with faster GDP 
growth. This is because backward and forward input-output linkages are strongest in manufacturing and the scope for capital accumulation, technological progress, economies of scale and knowledge spillover are strong. Further, there is a strong causal relationship between manufacturing output growth and labor productivity because of a deepening division of labor, specialization, and learning-by-doing and the scope for productivity gains is large due to economies of scale; (ii) industrialization requires a basis in agricultural modernization to ensure food supply and labor will transfer from other sectors to manufacturing. As manufacturing grows, productivity across the economy will rise even in agriculture and services through positive spillovers such as technological knowhow and complementary markets in services. Kaldor argued that the agriculture and industrial sectors are not only connected by the Lewis labor transition (the elastic supply of labor is due to industry wages exceeding agriculture wages) but also because agriculture creates autonomous demand for the manufacturing sector and thus land reform is required if agriculture is not to hinder ST; (iii) aggregate demand should be managed to ensure growth (e.g. policies on public investment, taxation, directed credit); and (iv) as exports become increasingly important as a source of demand for the manufacturing sector as the economy grows, global competition requires temporary domestic industry protection accompanied by export-led growth policies. ${ }^{5}$ In sum, for Kaldor, the virtuous cycle or Myrdal's cycle of cumulative causation is that demand and output growth fuel productivity growth due to increasing returns to scale which in turn fuels capital accumulation.

It is Kaldor's second law, also known as Kaldor-Verdoorn law, that contains a tension of particular importance to ST and inclusive growth. The Kaldor-Verdoorn (respectively, 1966 and 1949) coefficient is the employment elasticity of growth. The more manufacturing grows the more productivity grows across the whole economy because manufacturing provides capital goods across the economy. This is because increases in manufacturing employment raise agriculture productivity (as labor migrates) and because the manufacturing sector is the only sector with static and dynamic returns to scale due to new processes. ${ }^{6}$ Kaldor's (1978 [1966]) interpretation of Verdoorn (1949) is that output growth induces improvements in labor productivity (assuming an elastic labor supply) and not vice versa. In contrast, the hypothesis of neoclassical models such as Solow is that productivity growth is due to technological progress. Verdoorn's argument was one of cumulative causation 
where demand rather than supply determines the rate of accumulation. From this basis Kaldor (and later Thirlwall) developed models where the growth of exports leads to specialization which then leads to increases in productivity and skills improvements. This then causes resources to move to the export sector. ${ }^{7}$

\subsection{Economic Development with Structural TRANSFORMATION: LEWIS REVISITED}

Arthur Lewis (see notably, 1954, 1958, 1969, 1972, 1976, 1979) provided one of the best-known models of economic development in developing countries. Although sixty years old in its earliest iteration, the model remains relevant today to developing countries (see for contemporary discussion, Gollin, 2014). The dual model provides a heuristic device or an ideal type, in the Weberian sense, for thinking about structural transformation and economic development with an emphasis on labor, which is the factor of production that dominates most developing countries.

Lewis argued that the driver of capital accumulation was a sectoral movement of labor, from the "traditional" or "subsistence" or "noncapitalist" sector (of low productivity, low wage, priced to average product not marginal product, and thus with widespread disguised unemployment) to the "modern" or "capitalist" sector (of higher productivity, and where wages are set by productivity in the "subsistence sector"). Crucial is the existence of surplus labor in the traditional or noncapitalist sector. Because of this wages are set just above subsistence across the whole economy, leading to the transfer of labor over time from traditional or noncapitalist to modern or capitalist sectors and the capture of labor productivity gains to capitalists as profits as these are the source of growth via reinvestment. The floor for wages is institutionally set at subsistence. When the surplus labor disappears an integrated labor market and economy emerge and wages will then start to rise.

The Lewis model was intended as a critique of the neoclassical approach in that labor is available to the modern or capitalist sector of an economy not in a perfectly elastic supply but upward sloping rather than flat, and with a distinction between surplus-producing labor and subsistence labor (the latter of which was a negligible source of net profits for reinvestment, which Lewis saw as the driver for growth). Lewis also 
rejected the assumptions of neoclassical economists of perfect competition, market clearing and full employment and Lewis (see 1958, pp. 8, 18) made the distinction between productive labor, which produced a surplus, and unproductive labor, which did not.

There have been various critiques of the Lewis model, many of which are of a "red herring" variety as Ranis (2004, p. 716) puts it, meaning they are easily responded to or actually criticisms of Lewisians rather than the writing of Lewis himself. Many relate to the assumption of labor abundance in the subsistence sector (and thus the dominance of the wage from that sector across the economy), and the emergence of the urban informal sector, although Lewis's conception of surplus labor explicitly included the urban informal sector (see discussion in Fei \& Ranis, 1964; Harris \& Todaro, 1970; Minami, 1973; Rosenzweig, 1988; Schultz, 1964; Todaro, 1969).

A set of contemporary challenges throws up greater levels of complexity. First, domestic labor migration may not be permanent but circular (back-and-forth) or "commuting." Second, the contemporary scale of inter-sectoral resource flows via the growth of remittances further blurs the line between sectors. Finally, the Lewis transition can take a variety of forms beyond the anticipated one by Lewis and it is by no means guaranteed that the transfer will be from low- to high-productivity activities as flagged by McMillan and Rodrik (2011). A transfer from low-productivity agriculture to low-productivity services has been the experience of many developing countries and a reversing of the Lewis transition has also been a phenomenon noted in a number of developing countries in "premature deindustrialization."

In sum, the Classical School approach to economic development is that economic development is driven by changing structures of GDP and employment that lead to productivity growth. As a result of the productivity rates between sectors differing so substantially, the transfer of labor and production is a major source of productivity gains and thus economic growth.

\section{Notes}

1. One hybrid is Diao et al. (2017, pp. 3-4) seek to link the structural dualism of Lewis with the neoclassical model by arguing that the neoclassical model shows the growth process within the modern sector and the dual model shows the relationship among sectors. 
2. McMillan and Rodrik (2011) find that countries with a large share of exports in natural resources tend to experience growth-reducing structural transformation and, even if they have higher productivity, cannot absorb surplus labor from agriculture. In a similar vein, Gollin et al. (2016), too, argued that natural resource exports drive urbanization without structural transformation because natural resources generate considerable surplus which is spent on urban goods and services, and urban employment tends to be in non-traded services. McMillan and Rodrik (2011) also find that an undervalued (competitive) exchange rate, which operates effectively as a subsidy on industry and labor market characteristics (so labor can move across sectors and firms easily), leads to growth-enhancing structural transformation.

3. There are a set of methodological questions too. Syrquin (2007) briefly identifies such questions and they include defining what is meant by "sectors" and thus what ST means (inter- or intra-depends on the breadth of definitions of sectors) and the blurring between "services" and "manufacturing" due to technological advances and outsourcing.

4. Targetti (1988) highlights Kaldor's contribution in cumulative causation rather than timeless "equilibrium."

5. Kaldor also took the two-sector model to be applicable to trade between developing and developed countries through the export of agriculture products from the former and import of manufactured goods from the later. He argued that international trade could make developing countries poorer because liberalization would increase agriculture exports which are produced at decreasing returns that are not sufficient to compensate for the loss of manufacturing exports, which is a sector which produces increasing returns.

6. In contrast, the neoclassical position on growth and employment is based on Okun's (1962) law which states that changes in the GDP growth rate and rate of unemployment have a negative association. This was critiqued for not accounting for changes that could be due to alterations in labor force participation (see Basu \& Foley, 2013).

7. Thirlwall (1979) added that the rate of economic growth will not exceed the rate of growth of exports to the income elasticity of demand for imports. In short, he argued that there is a balance of payments constraint on growth.

\section{REFERENCES}

Basu, D., \& Foley, D. K. (2013). Dynamics of output and employment in the US economy. Cambridge Journal of Economics, 37(5), 1077-1106.

Chenery, H. B. (1960). Patterns of industrial growth. The American Economic Review, 50(4), 624-654.

Chenery, H. B. (1975). The structuralist approach to development policy. The American Economic Review, 65(2), 310-316. 
Chenery, H. B. (1979). Structural change and development policy. Washington, DC: World Bank and Oxford: Oxford University Press.

Diao, X., McMillan, M., Rodrik, D., \& Kennedy, J. F. (2017). The recent growth boom in developing economies: A structural-change perspective (NBER Working Paper Series No. 23132). Cambridge, MA: NBER. Retrieved from http:// www.nber.org/papers/w23132.

Fei, J. C. H., \& Ranis, G. (1964). Development of the labor surplus economy: Theory and policy. Homewood, IL: Richard A. Irwin.

Gollin, D. (2014). The Lewis model: A 60-year retrospective. Journal of Economic Perspectives, 28(3), 71-88.

Gollin, D., Jedwab, R., \& Vollrath, D. (2016). Urbanization with and without structural transformation. Journal of Economic Growth, 21(1), 35-70.

Harris, J. R., \& Todaro, M. P. (1970). Migration, unemployment and development: A two-sector analysis. American Economic Review, 60, 126-142.

Herrendorf, B., Rogerson, R., \& Valentinyi, A. (2014). Growth and structural transformation (NBER Working Paper Series No. 18996). Cambridge, MA: NBER. Retrieved from http://www.nber.org/papers/wl8996.

Hirschman, A. O. (1958). The strategy of economic development. New Haven, CT: Yale University Press.

Kaldor, N. (1957). A model of economic growth. The Economic Journal, 67(268), 591-624.

Kaldor, N. (1978 [1966]). Causes of the slow rate of economic growth of the United Kingdom. Cambridge: Cambridge University Press.

Lewis, W. A. (1954). Economic development with unlimited supplies of labour. The Manchester School of Economic and Social Studies, 22(2), 139-191.

Lewis, W. A. (1979). The dual economy revisited. The Manchester School, 47(3), 211-229.

McMillan, M. S., \& Rodrik, D. (2011). Globalization, structural change and productivity growth (NBER Working Paper Series No. 17143). Cambridge, MA: NBER. Retrieved from http://www.nber.org/papers/w17143.

Minami, R. (1973). The turning point in economic development: Japan's experience. Tokyo: Kinokuniya.

Myrdal, G. (1957a). Rich lands and poor: The road to world prosperity. New York: Harper \& Brothers.

Myrdal, G. (1957b). Economic theory and underdeveloped regions. London: Gerald Duckworth \& Co. Ltd.

Myrdal, G. (1968). Asian drama: An inquiry into the poverty of nations. New York: Pantheon Books.

Palma, J. G. (2005). Four sources of "de-industrialization" and a new concept of the "Dutch disease". In J. A. Ocampo (Ed.), Beyond reforms: Structural dynamic and macroeconomic vulnerability (pp. 71-116). Palo Alto, CA and Washington, DC: Stanford University Press and World Bank.

Ranis, G. (2004). 'Arthur Lewis' contribution to development thinking and policy (Discussion Paper 891). Economic Growth Center Yale University. 
Rodrik, D. (2016). Premature deindustrialization. Journal of Economic Growth, 21(1), 1-33.

Rosenzweig, M. (1988). Labor markets in low income countries. In H. Chenery \& T. N. Srinivasan (Eds.), Handbook of development economics (Vol. 1). Amsterdam: North Holland Press.

Solow, R. M. (1956). A contribution to the theory of economic growth. The Quarterly Journal of Economics, 70(1), 65-94.

Storm, S. (2015). Structural change. Development and Change, 46, 666-699.

Sutirtha, R., Kessler, M., \& Subramanian, A. (2016). Glimpsing the end of economic history? Unconditional convergence and the missing middle-income trap (Centre for Global Development Working Paper 438). Washington, DC: CGD.

Syrquin, M. (2007). Kuznets and Pasinetti on the study of structural transformation: Never the Twain shall meet? (International Centre for Economic Research Working Paper 46). Torino, Italy.

Targetti, F. (1988). 'Nicholas Kaldor', Teoria e politica economica di un capitalismo in mutamento. Bologna: Società Editrice II Mulino S.p.A.

Targetti, F. (2005). Nicholas Kaldor: Key contributions to development economics. Development and Change, 36(6), 1185-1199.

Thirlwall, A. P. (1979). The interaction between income and expenditure in the absorption approach to the balance of payments. Journal of Macroeconomics, Elsevier, 1(2), 237-240.

Thirlwall, A. P. (1982). Deindustrialisation in the UK. Lloyd's Bank Review, 134, 22-37.

Thirlwall, A. P. (2011). Balance of payments constrained growth models: History and overview. PSL Quarterly Review, 64(259), 307-351.

Todaro, M. P. (1969). A model of labor migration and urban unemployment in less developed countries. The American Economic Review, 59, 138-148.

Open Access This chapter is licensed under the terms of the Creative Commons Attribution 4.0 International License (http://creativecommons.org/licenses/ by $/ 4.0 /$ ), which permits use, sharing, adaptation, distribution and reproduction in any medium or format, as long as you give appropriate credit to the original author(s) and the source, provide a link to the Creative Commons license and indicate if changes were made.

The images or other third party material in this chapter are included in the chapter's Creative Commons license, unless indicated otherwise in a credit line to the material. If material is not included in the chapter's Creative Commons license and your intended use is not permitted by statutory regulation or exceeds the permitted use, you will need to obtain permission directly from the copyright holder.

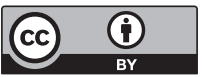

